\title{
New York City’s Brownfield Redevelopment Program: Economic Catalyst or Taxpayer Giveaway?
}

\author{
Tatyiana Gordon \\ NYU Tandon School of Engineering, United States \\ E-mail: tatyiana.gordon@nyu.edu
}

Received: May 20, $2021 \quad$ Accepted: August 2, $2021 \quad$ Published: August 25, 2021

doi:10.5296/jee.v12i2.18633ＵRL: https://doi.org/10.5296/jee.v12i2.18633

\begin{abstract}
The New York State Department of Environmental Conservation (DEC) and the New York City Office of Environmental Remediation (OER) manage and coordinate brownfield cleanup programs. These are intended to promote environmental restoration and redevelopment of underutilized or abandoned properties that have been affected by the presence or discharges of oil or hazardous substances. This paper seeks to determine whether these programs have achieved the goals and objectives sought by decision makers and if the cost of those achievements in terms of public money subsidies and forgone tax revenue have been commensurate with the realized benefits.

The DEC brownfield program offers financial incentives, such as tax credits, as well as regulatory benefits (limited liability protections) to promote alternatives to greenfield development. OER efforts are New York City centric with incentives divided into three sectors: procedural, legal, and financial with a major goal of reducing remedial (cleanup) timeframes. To evaluate the effectiveness of the New York City Brownfield program changes in property values over time were evaluated. The five New York City counties experiencing the two highest percent increases in property values also claimed the highest brownfield credits. Queens and Brooklyn received most brownfield credits during this period but also experienced the most redevelopment. These and other data illustrate a return on the brownfield investment (ROBI) credit of about one to six; or one dollar in brownfield credit stimulating six dollars in project spending. New York City counties' ROBI is consistent with all other New York State County ROBI's: roughly six dollars in redevelopment activity being stimulated by one dollar in brownfield credit. The roughly $\$ 6$ ROBI presented here is similar to ROI's for other public services such as disease prevention and incarceration intervention.
\end{abstract}

Keywords: Brownfield, Greenfield, Redevelopment, Economy, New York City, Return on investment 


\section{Introduction}

In 2003, the New York State Department of Environmental Conservation (DEC) implemented the New York State Brownfield Cleanup Program created by legislature in order to coordinate and promote the environmental restoration and redevelopment of underutilized or abandoned properties that have been affected by the presence or discharges of oil or hazardous substances (Brownfield Cleanup). By establishing special, streamlined regulatory guidelines for these types of sites, in combination with offering economic redevelopment funding such as grants, loans, and tax incentives, the DEC sought to encourage a public-private partnership that leads to the quick return of the damaged property to productive use. This state-wide effort was complemented in 2008 through the creation of the New York City Mayor's Office of Environmental Remediation (OER). The OER works with developers and property owners to streamline Brownfield cleanup and is complemented by a New York State DEC redevelopment effort, launched in August 2010, focused on addressing the over 1,500 Brownfield sites within the New York City boroughs of Queens, Brooklyn, Manhattan, Staten Island, and the Bronx (Larsen).

The New York State DEC program has been operating for over 15 years with a total of 452 Brownfield Sites enrolled and the New York City OER program has been in place for over 10 years. It is now appropriate to examine whether these taxpayers' funded endeavors have achieved the goals and objectives sought by public policy decision makers and if the cost of those achievements in terms of public money subsidies and forgone tax revenue have been commensurate with the realized benefits.

\section{Greenfields vs. Brownfields}

Greenfield development - constructing buildings and supporting infrastructure on previously non-urbanized land such as agricultural fields or forests - typically takes place at the edges of cities or towns or in the suburbs where significant residential or commercial use has yet to occur. Greenfields are easier to repurpose as the cost of raw land generally is less expensive, demolition or environmental cleanup is not required, there likely is room for later development phases (project add-ons), and design/engineering options are less constrained. In addition, the local community may welcome the development as a way to revitalize or expand its tax base and bring public amenities to the area (e.g., improved roads or sewer systems).

However, greenfield development can result in habitat destruction or loss, an increase in urban sprawl, and there is always the risk of project failure if tenants or residents find the location undesirable or too remote from center city. While effective planning and environmental protections can mitigate some of these impacts, the loss of open space remains a major concern for many local and statewide governing bodies (Brownfield Development).

In contrast, brownfield development is the construction or expansion of buildings and related infrastructure on abandoned or under-utilized property that previously had been used for commercial or industrial purposes (DiNapoli). It is very different from its greenfield counterpart. Examples of brownfield sites include decommissioned small commercial lots 
such as dry cleaners and old gas stations, as well as old factories, and deserted buildings. These types of sites often have preexisting structures which require removal before new construction can start. Design and engineering concepts will be limited by the need to consider integration of project lay-out and facilities with existing infrastructure.

The defining driver of brownfield development, and what differentiates it from greenfield construction, is that restoration of these sites needs to address the presence of oil or hazardous substances which have been discharged to the environment and potentially contaminated soil and ground water. The reason to suspect contamination is a key element in differentiating a greenfield from a brownfield site. When an abandoned or underutilized property is not being used to its maximum potential due to the need of some form of decontamination, remediation efforts and site preparation can make project costs extremely high, often beyond the inherent value of the property. Although brownfield redevelopment may remain economically viable if the location of the site is highly attractive, environmental remediation is still expensive and time consuming and is considered a critical path item that must be resolved before new construction can even begin.

Despite these disadvantages, brownfield redevelopment is a highly desirable community goal. It reduces urban sprawl, preserves open space, helps to maintain existing ecologies (habitats), creates jobs, returns abandoned or under-utilized property to productive use within the community, and improves surrounding property values. These and other environmental and economic benefits, such as lessening carbon reliance, within local communities, especially when applied within one of the most densely built-up areas of the United States (the New York City metropolitan region) are not insignificant. One of the major hurdles facing developers in New York City is that there is very little vacant land other than that which is known or suspected to be contaminated, this makes brownfield development a foremost component of the city's restoration strategy. Policymakers have long recognized that given the challenges associated with this type of redevelopment, regulatory and financial incentives are needed to encourage private sector interest and investment in these types of sites.

\section{A Tale of Two Programs}

The DEC Brownfield Cleanup Program offers financial incentives, such as tax credits, as well as regulatory benefits (limited liability protections) to promote alternatives to greenfield development. One of the program's main goals is to remove or mitigate the initial barriers inhibiting urban brownfield development, such as uncertainty in environmental remediation (DiNapoli).

To participate, developers or property owners schedule a pre-application meeting to ensure that their site is not part of the relatively small universe of properties that are ineligible because it is:

1) Listed with DEC as Class 1 (the contamination level would constitute a significant threat to the public health and the environment) or Class 2 (the hazardous waste disposal on-site is listed on the Federal National Priorities List (NPL)) facility on the New York State Registry of Inactive Hazardous Waste Disposal Sites; (Site Classifications) or 
2) On the United States Environmental Protection Agency (USEPA) National Priorities (Superfund) List; or

3) Is a commercial facility that treats, stores, or disposes of hazardous waste; or

4) Is subject to cleanup under Article 12 of New York's Navigation Law, which deals with oil spill prevention, control, and compensation; or

5) Is subject to on-going federal or state environmental enforcement actions.

Over the past 12 years, approximately 915 sites have participated in the New York State Brownfield redevelopment program (NYSDT). About 33 percent of these properties were within New York City. DEC estimates that this has resulted in the redevelopment of over 300 properties. Cost to taxpayers in terms of grants and other related funding, as well as deferred tax revenue, has been estimated to be $\$ 2.75$ billion. Data are not available for sites that entered, but later withdrew, from the program.

Until relatively recently, the remediation of brownfield sites throughout New York State have been led by the DEC but with the establishment of the OER, a more focused, New York City centric program became available; something that no other metropolitan area had tried before, as New York City remains the first and still only municipal brownfield program. The incentives offered by the OER Brownfield Redevelopment Program can be divided into three sectors: procedural, legal, and financial. The most important procedural incentive includes a streamlined (faster) process for the characterization of site contamination and subsequent remediation, which, to some developers, can be seen as even more valuable than the financial incentives. By getting through the program at a quicker pace, the tax credits that developers saving can result in larger returns on capital investment in the long run through things such as loans and financing opportunities. Outside of the OER Brownfield program, environmental site investigation and cleanup can take as long as 20 years and serves as a major deterrent to private sector investment. Within the New York City Brownfield program, this timeframe is reduced, on average, to about 10 years (BCP Certificates of Completion).

As for the legal incentives, sites that are admitted into the program are granted a limited waiver of liability for contamination that remains on the site. In general, this means that the developer or purchaser of the brownfield site is not subject to environmental enforcement actions or penalties related to the presence of soil or ground water contamination so long as they did not cause or contribute to the release of those substances, they cooperate with cleanup efforts, and they comply with all land use and institutional controls that may be imposed on the site as a result of the cleanup (e.g., inspection of caps or conducting long-term ground water monitoring) (EPA, 2020).

The final and most important incentive of the New York City Brownfield Remediation Program is financial. This takes the form of tax credits, coming from the state program, which are calculated as a percentage of the cost of the site cleanup, remediation of any contaminants, and the overall redevelopment investment. These can be credited against state taxes and can range from $\$ 60,000$ for certified projects and up to $\$ 100,000$ for Preferred Community Development Projects, which are those that provide specific benefits to the 
surrounding local communities. Some of which include affordable housing, community amenities, and health care facilities (OER, 2020).

Since the founding of the New York City Brownfield program in 2010, over 900 sites have participated in it and been issued over $\$ 37$ billion in tax credits. These redevelopment projects have generated roughly $\$ 1.3$ billion annually in property tax revenues and created over 40,000 jobs (which are counted only for sites that have received their Certificate of Completion, so this number may be even higher). Data are not available as to how many of these projects would have gone forward without the incentives offered through the OER Brownfield program.

\section{Is New York City's Brownfield Program a Good Deal for Taxpayers?}

The New York City Brownfield Redevelopment Program appears to be an effective mechanism to establish the public-private partnerships needed to spur development of marginal properties, repurpose abandoned or underutilized land, and provide meaningful economic benefits to the community. However, program metrics need to be evaluated not only based on short-term economic returns but also within its stated goal to: "...mitigate the threat to public health and the environment from contaminated sites” (Environmental).

Since its inception, there have been thousands of site applicants with around 900 of these being admitted to the OER program. Out of these 351 sites admitted, 166 of them were remediated and received a DEC Certificate of Completion, COC, qualifying them for tax and other governmental incentives (New York State).

Thus, a respectable rate of 47 percent of the admitted sites had fully completed the NYC program. Of the $166 \mathrm{NYC}$ sites that were eligible for incentives, there were cases in which the projects qualified for tax credits that exceeded environmental cleanup costs and some sites received credits in excess of $\$ 100$ million. These examples, albeit rare, demonstrated the need for programmatic reform to ensure that developers did not reap windfall profits at the expense of New York City taxpayers. These isolated cases spurred the need for new regulations to make certain that brownfield program benefits were shared equitability among all the stakeholders (DiNapoli).

In 2009 the New York State Division of the Budget (DOB) intervened and promulgated regulations to address its concern that the Brownfield Redevelopment Program represented a significant financial risk to the state revenue. Additional restrictions were put in place tightening the requirements for sites that could be admitted to the program. This acted as a means to affirm that program incentives offered to developers were commensurate with anticipated benefits to the taxpayer. These new rules excluded sites that had minor environmental issues and, importantly, were already in areas of high interest to real estate developers (DiNapoli). Despite these recently enacted restrictions, the question remains as to whether the New York City Brownfield Program still is providing developers too many benefits while short-changing taxpayers.

One way to evaluate the effectiveness of the New York City Brownfield program is to look at property values over time (Figure 1). While residential property values are not an ideal 


\section{Macrothink}

measure, they do provide an indication as to whether brownfield redevelopment is influencing a community.

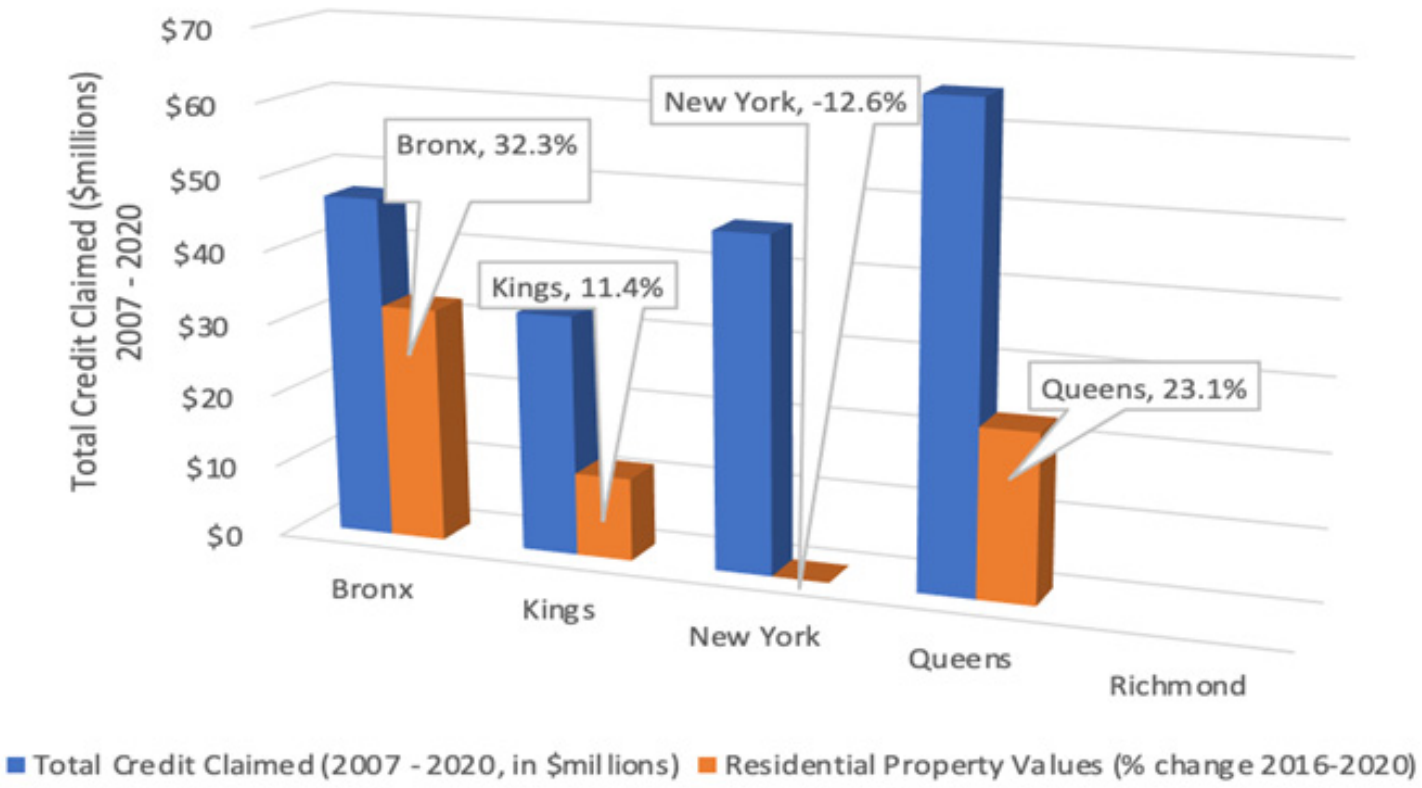

Figure 1. Property values vs. claimed brownfield credits

The difference in years from credit claimed (2007-2020) to change in property value (2016-2020) has been considered because it takes time for projects to be designed, built, and placed into service and for the overall impact of the redevelopment to filter through the community. While other socioeconomic factors will obviously play a role in driving residential property values, particularly in New York County (Manhattan) it is interesting to note that the counties experiencing the two highest percent increases in property values also claimed the highest brownfield credits. 


\section{Macrothink}

Table 1. Compares New York City project costs to issued brownfield credits

\begin{tabular}{|c|c|c|c|c|c|}
\hline $\begin{array}{l}\text { NYC } \\
\text { County }\end{array}$ & $\begin{array}{l}\text { Total } \\
\text { Project } \\
\text { Cost }(\$ 10 \\
\text { million) }\end{array}$ & $\begin{array}{l}\text { Total } \\
\text { Brownfield } \\
\text { Credit (\$10 } \\
\text { million) }\end{array}$ & $\begin{array}{l}\% \text { NYC } \\
\text { Counties - } \\
\text { Total Cost }\end{array}$ & $\begin{array}{l}\text { \% NYC } \\
\text { Counties - } \\
\text { Total Credit }\end{array}$ & $\begin{array}{l}\text { Return on } \\
\text { Brownfield Credit } \\
\text { Investment } \\
\text { (ROBI) }\end{array}$ \\
\hline Bronx & 98 & 18 & $3 \%$ & $3.6 \%$ & 5.4 \\
\hline Kings & 1,030 & 160 & $31 \%$ & $30.9 \%$ & 6.4 \\
\hline New York & 507 & 78 & $15 \%$ & $15.2 \%$ & 6.5 \\
\hline Queens & 1,670 & 260 & $51 \%$ & $50.3 \%$ & 6.4 \\
\hline Richmond & --- & --- & $0 \%$ & $0.0 \%$ & --- \\
\hline Total & 3,305 & 517 & $100 \%$ & $100 \%$ & 6.2 \\
\hline
\end{tabular}

Source: Elliman Report, Brownfield Redevelopment Credit.

For New York City counties (information was not available for Richmond County - Staten Island), total credits issued between 2016 and 2019 were approximately $\$ 5.2$ billion versus project costs of roughly $\$ 33$ billion. Queens and Brooklyn received the majority of brownfield credits during this period but also experienced the most redevelopment. These data illustrate a return on the brownfield investment (ROBI) credit of about \$27.8 billion or one dollar in brownfield credit helped to stimulate six dollars in project spending. Presumably, most of these financial project cost flowed to the surrounding local community.

To provide a wider perspective for the New York City program, Table 2 compares New York City County brownfield development costs and credits issued to the total of these two categories for the remaining 57 New York state counties. 


\section{Macrothink}

Table 2. New York City Counties Brownfield Costs and Credits Summary (2016-2019) Compared to All Other New York counties

\begin{tabular}{|c|c|c|c|c|c|}
\hline $\begin{array}{l}\text { NYC } \\
\text { County }\end{array}$ & $\begin{array}{l}\text { Total } \\
\text { Project } \\
\text { Cost }(\$ 10 \\
\text { million) }\end{array}$ & $\begin{array}{l}\text { Total } \\
\text { Brownfield } \\
\text { Credit (\$10 } \\
\text { million) }\end{array}$ & $\begin{array}{l}\text { New York City } \\
\text { Counties as a \% of } \\
\text { all Counties - Total } \\
\text { Project Cost }\end{array}$ & $\begin{array}{l}\text { New York City } \\
\text { Counties as a \% of } \\
\text { all Counties - Total } \\
\text { Brownfield Credit }\end{array}$ & $\begin{array}{l}\text { Return on } \\
\text { Brownfield } \\
\text { Investment } \\
\text { (ROBI) }\end{array}$ \\
\hline Bronx & 98 & 18 & $0.6 \%$ & $0.8 \%$ & 6.4 \\
\hline Kings & 1,030 & 160 & $6.5 \%$ & $6.7 \%$ & 6.5 \\
\hline New York & 507 & 78 & $3.2 \%$ & $3.3 \%$ & 6.4 \\
\hline Queens & 1,670 & 260 & $10.6 \%$ & $11.0 \%$ & 6.4 \\
\hline Richmond & --- & --- & $0.0 \%$ & $0.0 \%$ & --- \\
\hline \multicolumn{6}{|l|}{ NY City } \\
\hline County & & & & & 6.4 \\
\hline Total & 3,305 & 517 & --- & --- & \\
\hline \multicolumn{6}{|l|}{ All Other } \\
\hline Counties & 15,793 & 2,371 & $21 \%$ & $22 \%$ & 6.7 \\
\hline New York & & & & & 6.6 \\
\hline State Total & 19,098 & $\$ 2,888$ & --- & --- & \\
\hline
\end{tabular}

Source: Elliman Report, Brownfield Redevelopment Credit.

The data in Table 2 support a finding that the New York City counties' ROBI (brownfield project spending divided by brownfield credits issued) is consistent with all other county ROBI's as well as the overall New York State ROBI: roughly six dollars in redevelopment activity being stimulated by one dollar in brownfield credit.

\section{Discussion}

There are numerous public policy reasons to encourage brownfield versus greenfield development, especially within the confines of New York City. The rudimentary economic analysis presented in this study offers some context as to the financial role brownfield credits play in pushing projects on contaminated sites to completion.

The main question, however, remains unanswered. While contaminated properties accepted into the OER and DEC programs need to undergo remediation, is New York State, through the NYC Brownfield Program, unnecessarily deferring significant revenues from these sites through the issuance of brownfield redevelopment credits? The earlier versions of these incentive programs seemed to indicate that the answer is yes, with later reforms helping to reassure policy makers that public monies were being more effectively utilized. This paper's analysis tends to indicate that the New York City and New York State brownfield programs 
drive not unsubstantial project spending, some portion of which may flow to host communities and result in long term increases to local property values.

The roughly \$6 ROBI presented here is contrasted with similar ROI's for other public services such as disease prevention (\$2.70 to \$5.42; Goetzel et al., 2005) and incarceration intervention (\$4.74 to \$19.62; Duwe, 2017). The New York City counties' ROBI's seem well-aligned when compared to these other societal ROI's. However, additional research is needed to determine whether further program limitations and possible reductions in incentives would prove useful to improve the likely benefits accrued from the use of scarce public monies.

\section{Acknowledgments}

The author wishes to express her gratitude to Dr. Robert Blauvelt and Ms. Susan Boyle for their critical review of this paper.

\section{References}

Brownfield Cleanup Program, Certificates of Completion. (2021, March 21). Retrieved from https://data.ny.gov/Energy-Environment/Brownfield-Cleanup-Program-Certificates-of-Compl et/ir93-7qzi/data

Brownfield Cleanup Program. (2018, July 10). Retrieved from https://esd.ny.gov/ brownfield-cleanup-program

Brownfield Development. (2018, January 02). Retrieved from http://www.prologis. com/brownfield-development

Brownfield Redevelopment Credit: Beginning Calendar Year 2005. (2021, March 21). Retrieved from https://data.ny.gov/Energy-Environment/Brownfield-Cleanup-ProgramCertificates-of-Complet/ir93-7qzi/data

DiNapoli, T. P. (n.d.). Overview of the New York State Brownfields Cleanup Program. State of New York Comptroller.

Duwe, G. (2017). The use and impact of correctional programing for inmates on pre- and post-release outcomes. U.S. Department of Justice, Office of Justice Programs, National Institute of Justice. Retrieved from https://www.ojp.gov/pdffiles 1/nij/250476.pdf

Elliman Report 2011-2020 Manhattan Decade Sales (Rep.). (n.d.). Retrieved https://www.millersamuel.com/files/2021/02/manhattan_10yr_2020_v4.pdf

Elliman Report Q4-2020 Brooklyn, NY Sales (Rep.). (n.d.). Retrieved https://www.elliman.com/resources/siteresources/commonresources/static\%20pages/images/c orporate-resources/q4_2020/brooklyn-q4_2020-highlights.pdf

Elliman Report Q4-2020 Manhattan, NY Sales (Rep.). (n.d.). Retrieved https://www.elliman.com/resources/siteresources/commonresources/static\%20pages/images/c orporate-resources/q4_2020/manhattan-q4_2020-highlights.pdf

Elliman Report Q4-2020 Queens, NY Sales (Rep.). (n.d.). Retrieved https:/www.elliman.com/resources/siteresources/commonresources/static\%20pages/images/c orporate-resources/q4_2020/queens-q4_2020-highlights.pdf 


\section{Macrothink}

Elliman Report Q4-2020 Riverdale, NY Sales (Rep.). (n.d.). Retrieved https://www.elliman.com/resources/siteresources/commonresources/static\%20pages/images/c orporate-resources/q4_2020/riverdale-q4_2020-highlights.pdf

Environmental Cleanup \& Brownfields. (n.d.). Retrieved from https://www.dec.ny.gov/chemical/brownfields.html

Goetzel, R. Z., Ozminkowski, R. J., Villagra, V. G., \& Duffy, J. (2005). Return on investment in disease management: a review. Health Care Finance Rev, 26(4),1-19.

Larsen, E. (2010, December 08). Overview of the New York City Brownfield Cleanup Program. Retrieved from https://www.lexology.com/library/detail.aspx?g=ea3e97b1-7c2e46da-81a9-7d35520b42c2

New York State, Department of Environmental Conservation. (2021, January 27). New York State's Brownfield Cleanup Program Marks Successful Year in 2020. Retrieved from https://www.dec.ny.gov/press/122249.html

NY Real Estate Market. (n.d.). Retrieved from https://www.realtor.com/ realestateandhomes-search/New-York/overview

Site Classifications. (n.d.). Retrieved from http://www.dec.ny.gov/chemical/8663.html

Summary of the Small Business Liability Relief and Brownfields Revitalization Act. (2017, July 26). Retrieved from https://www.epa.gov/brownfields/summary-small-businessliability-relief-and-brownfields-revitalization-act

Superfund: National Priorities List (NPL). (2021, February 08). Retrieved from http://www.epa.gov/superfund/superfund-national-priorities-list-npl

\section{Copyrights}

Copyright for this article is retained by the author(s), with first publication rights granted to the journal.

This is an open-access article distributed under the terms and conditions of the Creative Commons Attribution license (http://creativecommons.org/licenses/by/4.0/). 